\title{
Effect of seasonal cabbage cultivar (Brassica rapa L. ssp. Pekinesis) on the quality characteristics of salted-Kimchi cabbages during storage period
}

\author{
Eun Jeong Choi, Moon Cheol Jeong, Kyung Hyung Ku* \\ Research Group of Food Storage and Distribution, Korea Food Research Institute, Seongnam 463-746, Korea
}

\section{계절별 배추 품종에 따른 절임배추의 저장중 품질 특성}

\author{
최은정 · 정문철 · 구경형* \\ 한국식품연구원 저장유통연구단
}

\begin{abstract}
This study investigates the physicochemical, microbiological and sensory characteristics of seasonal salted-Kimchi cabbages to provide basic data on its uniform quality. Generally, seasonal salted-Kimchi samples had different pH values at initial storage periods, but there was no difference in $\mathrm{pH}$ between the seasonal samples when stored for longer periods. The samples from the fall and winter seasons were relatively low in acid and high in solid soluble content compared to samples from other seasons. Salted-Kimchi cabbages in the summer showed the highest microbiological number compared to samples from other seasons. In the sensory evaluation, there were differences in the appearance, aroma, and taste, depending on seasonal samples at different storage periods. The correlation coefficient between the quality characteristics in the seasonal samples showed a positive or negative correlation between the quality characteristics at $1 \%$ significant level. In the principal component analysis, F1 and F2 were shown the $51.81 \%$ and $\mathbf{1 4 . 2 3 \%}$ of the total variance $(66.21 \%$, respectively. In the PCA pattem of seasonal salted-Kimchi cabbages during storage periods, winter samples were distributed on the top of F2, spring samples were in the middle of F2, while the rest of the samples were distributed on the bottom of F2. According to increasing storage periods, initial storage samples were distributed at the left of $\mathrm{F} 1$, while other samples were located at the right of $\mathbf{F} 2$.
\end{abstract}

Key words : seasonal cultivars, salted-Kimchi cabbages, quality characteristics, cold storage

\section{서 론}

배추(Brassica campestris L. ssp. Pekinensis)는 호냉성 채 소로 약 $90 \%$ 이상이 배추 원물 상태로 유통되며 이중 약 $82.5 \%$ 가 우리나라의 대표 발효 식품인 김치 제조에 사용하 고 있다(1). 배추 총 생산량은 2013년 기준으로 2012년 2,151 천톤에서 배추 재배 면적과 단수 증가로 약 $21 \%$ 증가

*Corresponding author. E-mail : khku@kfri.re.kr Phone : 82-31-780-9052, Fax : 82-31-709-9876

Received 19 March 2015; Revised 28 April 2015; Accepted 10 June 2015.

Copyright (c) The Korean Society of Food Preservation. All rights reserved.
한 261만 2천톤으로 추정되고 있고, 재배 방법 등의 발달로 연중 배추를 생산하여 소비자에게 공급할 수 있게 되었다 $(2,3)$. 최근 사회 변화에 따른 식생활의 변화로 계절에 상관 없이 김치 제조에 가장 시간이 많이 소요되는 절임 배추를 이용하는 소비자의 비율이 김장철뿐만 아니라 연중 점차 늘고 있는 추세이다 $(4,5)$.

한편 절임배추에 관한 연구는 김치 연구와 함께 진행되 어 절임조건, 포장 방법, 소금 종류 등에 따른 절임배추의 품질 변화에 대한 연구(6-15)와 배추 품종, 재배 조건, 절임 공정이 절임배추와 김치 품질에 미치는 영향 등 절임배추와 김치를 연계하여 연구가 수행되었다(16-22). 현재 일부 소 규모 배추 절임업체에서는 김장철에만 생산을 하여 소비자 에게 제조 판매하고 있는 경우도 있으나, 대규모 절임배추 
제조업체에서는 연중 절임배추를 생산하여 소비자에게 공 급하고 있어 계절에 상관없이 품질이 균일한 절임배추를 공급하기 위해서는 이에 대한 연구가 요구되고 있다. 그러 나 이와 같은 연구는 대규모 김치 제조공장에서 기계화 절임 조건의 표준화를 위하여 공장 규모로 진행 시킨 연구 (14)와 계절별 절임배추의 제조 직후의 품질 특성에 연구 (24)가 일부 되어 있을 뿐 계절에 따른 절임배추 품질과 저장 기간 중 품질 특성 변화에 대한 관한 연구는 거의 없다.

본 연구는 대형 절임배추 제조 공장에서 제조된 계절별 절임배추 저장 중의 물리화학적 및 관능적 품질 특성을 조사하여 품질이 균일한 계절별 절임배추의 냉장 유통시 상품성을 유지할 수 있는 유통 기간과 김치 제조 공장에서 김치 제조가 가능한 절임배추의 저장 기간을 제시하기 위한 기초 자료로 이용하고자 수행되었다.

재 료

\section{재료 및 방법}

본 실험에 사용된 계절별 배추는 봄배추(춘광, 2013년 6월 수확), 가을배추(추광, 2013년 11월 수확), 월동배추(남 도장군, 2013년 3월 수확)는 전라남도 해남에서 재배한 것 이었고, 여름 배추는 강원도 평창에서 재배된 고랭지 배추 (2013년 9월 수확)를 실험에 사용하였다. 절임배추 제조는 해남 화원 농협(Haenam-gun, Jeollanam-do, Korea)에서 $\mathrm{HACCP}$ 절임배추 제조 라인에서 제조된 절임배추를 $0^{\circ} \mathrm{C}$ 로 유지된 냉장 수송차에 온도 로거를 부착하여 제조 직후 12 시간 이내로 제공받아 실험하였다. 이때 해남 화원농협 의 절임배추 제조 라인은 배추를 이절, 1 차 정선, 2 단계 절임, 4단계 세척, 선별, 탈수, 포장의 공정과정을 거쳤고, $\mathrm{HACCP}$ 규정하에 절임실, 세척수, 절임수, 절임배추의 품 온, 절임수 염도 및 절임배추 제조 후의 절임배추의 염도, $\mathrm{pH}$, 고형분 함량을 매일 측정하여 최종 절임배추의 균일성 을 유지하였다. 절임 공정 라인을 조사 분석한 결과 절임실 과 세척수 온도는 $15 \sim 20^{\circ} \mathrm{C}$ 였고, 절임수 염도 약 $10 ~ 14 \%$ 에 서 약 24 시간 절임을 한 후 $10 \sim 15^{\circ} \mathrm{C}$ 내외의 세척수로 4 단계 의 세척을 통과한 절임배추를 탈수 그물망 컨베이어에 약 5 분 6분 정도 탈수 한 후 포장 단계를 거친다. 본 실험에 사용한 시료는 각 계절별로 생산되어 $10 \mathrm{~kg}$ 단위로 포장된 절임배추 15 박스를 제공받았으며, 반포기당 절임배추의 무 게는 약 $1.5 \sim 1.8 \mathrm{~kg}$ 였고, 염도는 약 $1.3 \sim 1.5 \%$ 의 범위였다. 각 계절별로 반포기씩 비슷한 크기의 것을 취하여 polyethylene(PE) film으로 개별 포장한 후 $0^{\circ} \mathrm{C}$ 에 2 달간 저장 하면서 7일 간격으로 시료를 취하여 실험하였다.

\section{$\mathrm{pH}$ 및 적정산도}

절임배추 시료 반포기 약 $1.5 ~ 1.8 \mathrm{~kg}$ 를 $1 / 4$ 씩 세로로 자른 후 blender(MR-5550 MFP, Braun, Poland)로 갈아 반죽 (paste) 상태의 시료를 제조한 후 electrode를 사용하여 $\mathrm{pH}$ (827, Metrohm, Zfinyen, Switzerland)를 측정하였다. 적 정 산도는 blender로 간 반죽상태의 시료 $1 \mathrm{~g}$ 에 증류수를 $100 \mathrm{~mL}$ 첨가한 후 여과지로 여과한 다음 여액 $20 \mathrm{~mL}$ 를 취하여 $0.01 \mathrm{~N} \mathrm{NaOH}$ 용액으로 $\mathrm{pH}$ 가 8.3이 될 때까지 적정 하여 소비된 $0.01 \mathrm{~N} \mathrm{NaOH}$ 용액의 소비량을 구한 후 젖산으 로 환산하여 표시하였다(25).

\section{소금 함량 및 가용성 고형분 함량}

소금(나트륨) 함량은 절임배추 시료를 세로로 $1 / 4$ 씩 잘라 반죽 상태로 제조한 시료 $1 \mathrm{~g}$ 을 정확히 달아 $100 \mathrm{~mL}$ 로 희석한 후 여과한 여액 $10 \mathrm{~mL}$ 을 취하고 $2 \%$ potassium chromate $1 \mathrm{~mL}$ 를 넣어 $0.02 \mathrm{~N} \mathrm{AgNO}_{3}$ 용액으로 적정하는 Mohr법에 의해 측정하였다(26). 절임배추의 가용성 고형분 (soluble solid content)은 반죽 상태의 배추 시료를 거즈로 여과한 다음 디지털 당도계(PDX-1, VeeGee, Kirkland, WA, USA)를 이용하여 각 처리구당 5 회 반복하여 평균값을 구하 였다.

\section{총균수 및 유산균수 측정}

절임배추 중의 총균수와 유산균 수를 측정하기 위하여 $100 \mathrm{~g}$ 씩 취하여 $0.85 \%$ 멸균식염수 용액으로 10 배 희석한 후 stomacher(Bagmixer, Duksan, Seoul, Korea)를 이용하여 균질화 하였다. 균질액 $1 \mathrm{~mL}$ 을 취하여 $0.85 \%$ 멸균식염수에 단계적으로 희석하고 $1 \mathrm{~mL}$ 씩 pouring culture method로 접 종하였다. 각각 총균수(plate count agar)와 유산균수 (Lactobacilli MRS agar)는 $30^{\circ} \mathrm{C}$ 에서 48 시간 배양한 후 colony 수를 측정하여 colony forming unit( $\log \mathrm{CFU} / \mathrm{g})$ 으로 표시하였다(27).

\section{색도 및 조직감}

절임배추의 색도는 반죽 상태의 시료를 직경 $5 \mathrm{~cm}$, 높이 $5 \mathrm{~mm}$ 의 원형 플라스틱 틀에 넣어 색도계(CR-410, Minolta Co., Osaka, Japan)를 이용하여 측정하였다. 측정 전 표준백 판으로 보정한 후 사용하였으며 $\mathrm{L}$ (명도, lightness), a(적색 도, redness) 및 $\mathrm{b}$ (황색도, yellowness)값을 측정한 후 제조 직후의 시료를 초기값(대조구)으로 환산된 $\Delta \mathrm{E}$ 값

$\left(\sqrt{\left(L_{\text {sample }}-L_{\text {standard }}\right)^{2}+\left(a_{\text {sample }}-a_{\text {standard }}\right)^{2}+\left(b_{\text {sample }}-b_{\text {standard }}\right)^{2}}\right)$ 으로 나타내었다(28).

절임배추의 조직감 측정은 texture analyzer(TAXT-2, Stable Micro Systems, Ltd., Godalming, England)를 사용하 였고, puncture test를 시행하였다. 즉, 배추 표면의 중앙부분 에서부터 $100 \%$ 관통하면서 받는 최대 강도(hardness)를 측 정하였고, 시료 측정 횟수는 각 처리구당 15 회 반복하여 평균값을 구하였다. 이때 측정 조건은 probe $3 \mathrm{~mm}$, pretest speed $5 \mathrm{~mm} / \mathrm{s}$, test speed $0.5 \mathrm{~mm} / \mathrm{s}$, posttest speed $10 \mathrm{~mm} / \mathrm{s}$ 였 다. 이때 절임배추 시료는 일관성을 위해 포기 전체를 대표 
할 수 있는 겉잎에서 3 4번엽을 사용하여 줄기 부분 중 뿌리에서 $5 \mathrm{~cm}$ 떨어진 가장 두꺼운 부분을 측정 부위로 하였다.

\section{관능요원 선발}

절임배추 묘사 용어 도출은 원내 게시판을 이용하여 모 집을 하였으며, 이때 한국식품연구원에 근무하고 있는 연 구원 30명중 맛 차이에 예민한 패널 요원을 선정하기 위하 여 4가지 기본맛(단맛, 짠맛, 신맛, 쓴맛)에 대한 기본 맛 인지 검사 및 순위 검사를 실시하여 정답률이 $75 \%$ 이상인 요원과 지속적인 참여 의사와 표현 능력 등을 고려하여 8명을 패널 요원으로 선정하여 실험을 실시하였다(29).

\section{관능검사}

저장 중 절임배추 관능 특성의 강도 검사는 각 특성에 관한 훈련을 약 2 주간 한 후 각각의 묘사 특성 강도를 15 점 선척도로 평가하였다(29). 이때 선발된 절임배추의 묘사 특성은 외관에서 노란색의 선명도, 갈색 및 초록색의 강도,


광택 정도, 향미 특성에서 배추냄새, 짠냄새, 단냄새, 신냄 새였으며, 맛은 생배추맛, 짠맛, 단맛, 아린맛, 쓴맛, 신맛이 었고, 조직감은 아삭함과 질긴 정도였다. 각 특성의 평가는 외관, 향, 맛, 조직감, 후미 순으로 평가하였다. 패널 요원간 의 토의를 통하여 절임배추 색 평가 중 노란색 정도의 1점은 color guide(Pantone solid chips uncoated)에서 2000C, 15점 에 해당하는 시료는 $2007 \mathrm{C}$, 갈색의 1 점에 해당하는 시료는 $7506 \mathrm{C}, 15$ 점에 해당하는 시료는 $7512 \mathrm{C}$ 로 하였으며, 초록색 은 1 점에 해당하는 시료는 $580 \mathrm{C}, 15$ 점에 해당하는 시료는 $574 \mathrm{C}$ 로 하였다. 시료의 냄새는 3 번 정도 세게 들이마셔 냄새를 맡은 후 평가하게 하였고, 맛은 절임배추의 맛을 평가하였으며, 한 시료를 평가한 후에는 약 30초간의 휴식 시간을 취하게 하였다. 사용한 척도는 15 점 선척도로 사용 하였으며, 1 점은 해당 특성이 없다는 것을 나타내고 점수가 높아질수록 특성 강도가 강해지는 것으로 평가하게 하였다.

\section{통계분석}

계절별 절임배추의 물리화학적 및 미생물 품질 차이를
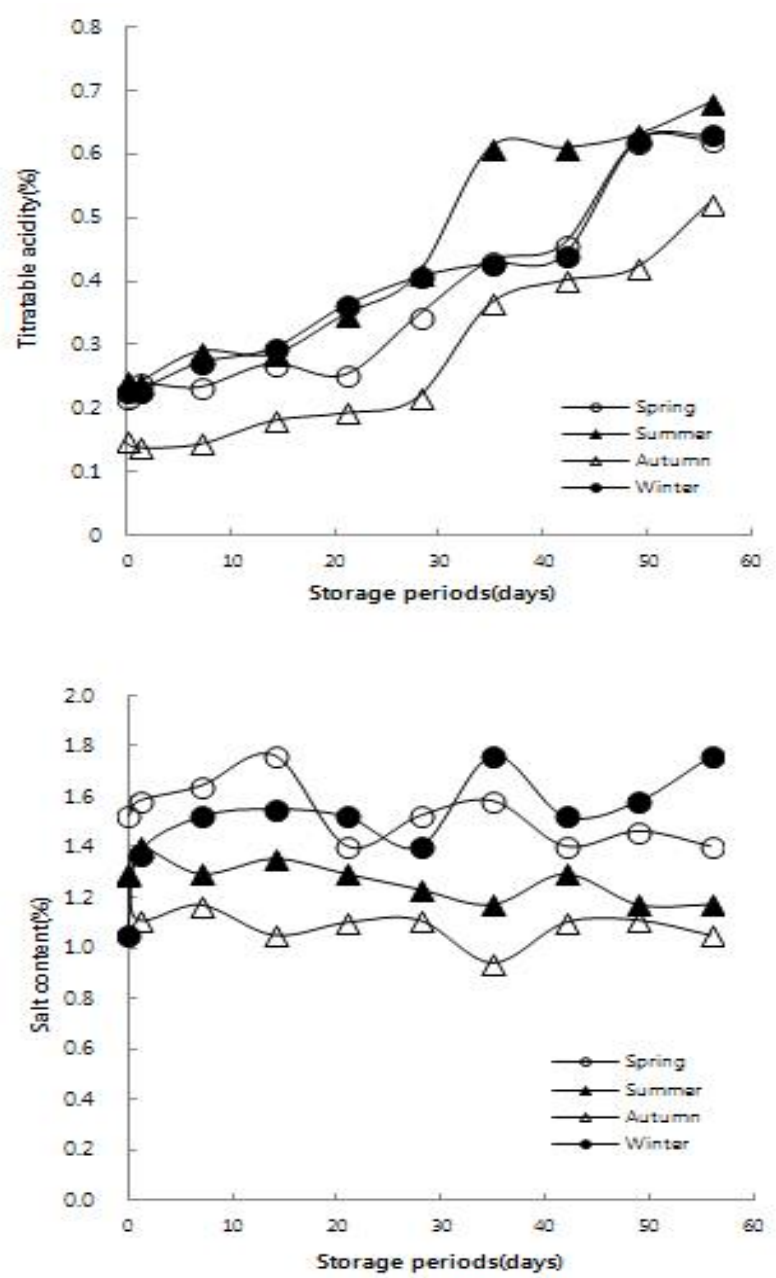

Fig. 1. Changes in the $\mathrm{pH}$, titratable acidity, soluble solid and salt content of seasonal salted-Kimchi cabbages in different storage periods. Value mean ( $\mathrm{n}=5$ ), $\mathrm{SD}$ value; $\mathrm{pH}< \pm 0.1$, titratable acidity $< \pm 0.01$, soluble solid content $< \pm 0.3$, salt content $< \pm 0.15$. 
파악하기 위해 분산분석(analysis of variance)을 실시하였 다. 또 이들 품질 요인간의 상관분석(correlation analysis), 주성분 분석(principle component analysis) 및 계층적 군집 분석(hierachical cluster analysis)을 실시하였다. 통계분석은 SPSS statistical analysis software(20, SPSS, Chicago, IL, USA)와 XLSTAT(2007.1, Addinsoft, NY, USA)을 이용하여 실시하였다.

\section{결과 및 고찰}

저장중 계절별 절임배추의 품질 특성

봄배추, 여름배추, 가을배추 및 월동배추를 이용하여 대 형 절임배추 공장에서 $\mathrm{HACCP}$ 조건에서 제조한 절임배추 의 $0^{\circ} \mathrm{C}$ 저장 중 $\mathrm{pH}$, 적정산도, 가용성 고형분 함량 및 소금 함량을 비교하였다(Fig. 1). $\mathrm{pH}$ 의 경우 절임배추 제조 직후 에는 5.90 6.03의 범위에서 저장기간이 증가함에 따라 점차 감소하는 경향을 보였다. 계절별로 보면 저장 14 일과 저장 20 일의 범위에서는 여름배추와 월동배추가 봄배추와 가을 배추보다 낮은 $\mathrm{pH}$ 를 보였으나 저장기간이 증가함에 따라 시료간 $\mathrm{pH}$ 의 차이를 보이다가 저장 기간 후반에는 큰 차이 없이 $\mathrm{pH} 4.3$ 내외의 범위를 보였다. 본 연구 결과에서 계절 별 절임배추의 초기 $\mathrm{pH}$ 는 Lee 등(17)과 Park 등(30)의 가을 김장 배추 10 종의 품종으로 동일 조건으로 제조한 절임배 추의 초기 $\mathrm{pH}$ 가 5.94 6.11의 범위 안에 포함되는 범위였다. 또 Lee 등(17)의 품종별 절임 가을배추의 $0^{\circ} \mathrm{C}$ 에서 32 일간 저장하면서 $\mathrm{pH}$ 를 비교한 결과 품종에 따라 $\mathrm{pH}$ 가 차이가 있었다는 결과와 유사하게 계절별 절임배추도 차이가 있었 다. 적정산도의 경우 가을배추 시료가 $0.16 \%$ 로 가장 낮은 값을 보인 반면, 봄배추와 가을배추가 각각 $0.23 ~ 0.24 \%$ 였 고, 여름 배추가 $0.28 \%$ 에서 저장 기간이 증가함에 따라 차이가 있었다. 가을 절임배추는 다른 계절의 절임배추보 다 저장 2 달 동안 가장 낮은 적정 산도를 보였다. 반면에
여름배추는 저장 28 일 이후 적정산도 함량이 2 3배 정도 높은 함량을 보였다. 각 계절별 절임배추의 초기 적정산도 는 Lee 등(17)의 초기 적정산도가 $0.09 \sim 0.11 \%$ 라고 보고된 결과와 비교할 때 본 실험 결과보다 약간 높은 범위를 나타 냈으나, Han 등(19)의 결과와는 유사하였다. 또 저장 중 적정 산도의 변화가 Lee 등(17)의 저장 32일에 0.13 0.22\% 로 품종 간에 차이는 있다고 보고한 결과와 달리 동일 저장 기간에서 비교적 높은 적정산도 범위를 보였는데, 이는 적 정 산도 측정 방법의 차이와 절임배추 원료의 염도 차이로 저장기간 중의 산생성 양의 차이에 의한 것으로 여겨진다.

배추의 가용성 고형분 함량의 경우 제조 직후 월동배추 가 $7.70^{\circ} \mathrm{Brix}$ 로 다른 계절의 시료보다 높은 값을 보였고, 여름배추와 가을배추 및 봄배추는 $5.95 \sim 6.20^{\circ} \mathrm{Brix}$ 에서 저 장 기간 내내 가을배추는 약 $6.00^{\circ} \mathrm{Brix}$ 내외를 유지한 반면 월동배추는 약 $7.00 \sim 8.00^{\circ} \mathrm{Brix}$ 범위를 여름 배추는 35 일까 지 약 $5.00^{\circ} \mathrm{Brix}$ 까지 감소하다가 그 이후에는 $4.50^{\circ} \mathrm{Brix}$ 를 유지하였다. 또 봄배추는 저장 14 일에는 약 $6.00^{\circ} \mathrm{Brix}$ 를 그 이후에는 $4.50 \sim 5.00^{\circ} \mathrm{Brix}$ 의 범위를 보였다. 이는 Lee 등(33) 의 봄배추의 품종별 가용성 고형분 함량을 조사한 결과 약 $2.73 \sim 3.23^{\circ} \mathrm{Brix}$ 와 비교하여 높은 함량을 보였고, 봄배추 와 가을배추의 생육 정도에 따라서 가을배추가 봄배추보다 높은 고형분 함량을 보였다는 연구(17)를 미루어 보아 배추 재배 계절에 따라서도 차이가 있는 것을 확인하였다. 절임 배추의 염도의 경우 봄배추는 $1.4 ~ 1.8 \%$, 여름배추는 $1.2 \sim 1.4 \%$, 가을배추는 $0.9 \sim 1.2 \%$ 내외, 월동배추는 $1.4 \sim 1.7 \%$ 범위의 염도를 보여 가을배추가 가장 낮은 염도를 나타냈 다. 이는 Lee 등(34) 월동배추와 봄배추의 삼투압을 조사한 결과 저장배추 즉, 월동배추의 삼투압이 봄배추와 다르다 고 보고한 연구 결과와 같이 계절별로 동일 농도의 절임수 에서도 계절별 배추의 염도 차이가 있었다.

절임배추 저장 중 총균수와 유산균 수를 조사한 결과(Fig. 2), 절임배추 제조 직후 총균수의 경우 여름 배추와 가을배 추가 각각 $6.70 \log \mathrm{CFU} / \mathrm{g}, 5.50 \log \mathrm{CFU} / \mathrm{g}$, 봄배추와 월동배
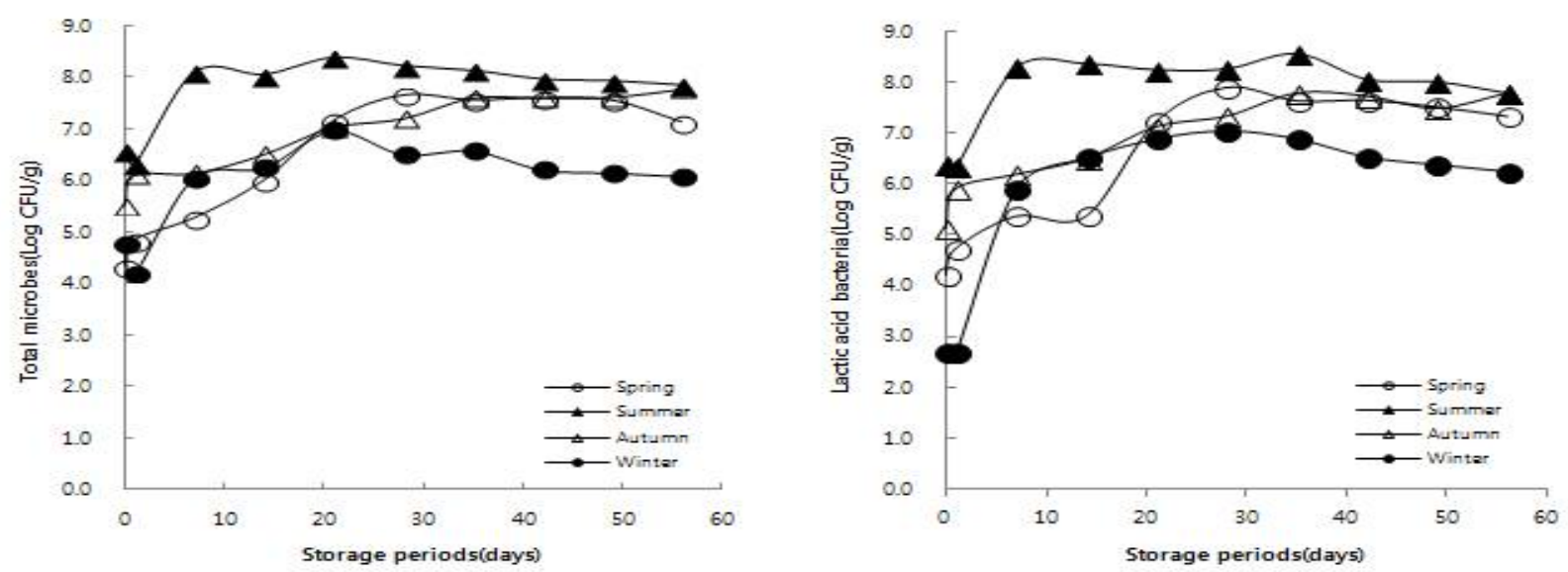

Fig. 2. Changes in the total numbers of microbes and lactic acid bacteria of seasonal salted-Kimchi cabbages in different storage periods. 
추는 4.50 4.90 $\log \mathrm{CFU} / \mathrm{g}$ 였다. 유산균의 경우 여름배추와 가을배추가 5.10 6.70 $\log \mathrm{CFU} / \mathrm{g}$, 봄배추와 월동배추가 각 각 2.80 4.20 $\log \mathrm{CFU} / \mathrm{g}$ 으로 나타나 총균수와 유산균 수 모두 여름배추와 가을배추가 높았다. 이는 $\mathrm{Ku}$ 등(24)의 계 절별 수확된 절임배추의 초기 균수와 유사하였고, $\mathrm{Kim}$ 등 (23)의 4 개 김치 업체에서 수거한 절임배추의 총균수가 4.17 8.08 $\log \mathrm{CFU} / \mathrm{g}$ 로 나타났다는 보고 결과 범위 안에 들어 있었다. 저장중의 총균수 변화를 보면 수확계절에 상 관없이 저장 기간이 증가함에 따라 총균수가 점차 증가하는 경향을 보이다가 어느 시점이 되면 그 균수를 유지하였다. 월동배추의 경우 저장 21 일까지 총균수가 증가하다가 그 이후부터는 $6.00 \log \mathrm{CFU} / \mathrm{g}$ 의 균수를 유지하였고, 봄배추와 가을배추는 저장 27일까지 총균수가 계속 증가하여 7.0 7.5 $\log \mathrm{CFU} / \mathrm{g}$ 까지 증가한 후 그 균수를 유지하였다. 반면에 여름배추의 경우는 저장 7일에 $8.10 \log \mathrm{CFU} / \mathrm{g}$ 으로 다른 계절의 절임배추보다 높았고, 그 이후 저장 내내 그 수준을 유지하였다. 유산균의 경우도 총균수와 유사한 패턴으로 여름 배추가 가장 높은 유산균수를 유지하였고, 봄배추와 가을배추가 비슷한 유산균수 증가 패턴을 유지하였다. 일 부 시료에서는 총균수보다 유산균수가 약간 많게 측정된 경우도 있으나, 통계적으로 유의성이 없었다. 이 결과는 Lee 등(17)의 품종별 가을배추로 제조한 절임배추를 $0^{\circ} \mathrm{C}$ 에 저장했을 때 초기 총균수가 6.93 7.08 $\log \mathrm{CFU} / \mathrm{g}$ 에서 저장 기간 30일 이후에는 6.98 8.30 $\log \mathrm{CFU} /$ 로 증가하였고, 유 산균의 경우도 초기 4.90 5.00 $\log \mathrm{CFU} / \mathrm{g}$ 에서 저장 30 일 이후 5.75 8.64 $\log \mathrm{CFU} / \mathrm{g}$ 으로 증가하였다는 결과와 유사 하였다. Fig. 3 은 저장 중 절임배추의 조직감과 색도 변화를 측정한 것으로 계절별 절임배추 제조 후의 조직감의 경우 경도(hardness)는 제조 직후의 여름 배추가 $1,170 \mathrm{~g}$ force로 가장 높았고, 나머지 계절별 배추는 $900 \mathrm{~g}$ force 내외의 비슷한 경도를 보였다. 절임배추의 경도는 절임시간, 절임 온도의 영향을 받는데, 낮은 온도에서의 절임이 높은 온도 에서의 절임보다 경도가 낮다는 보고(31)와 절임 온도가

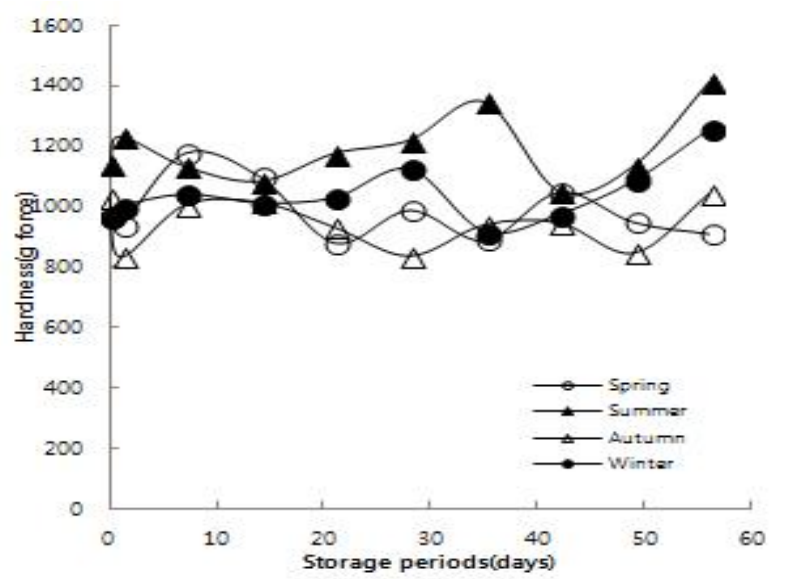

낮을 경우 경도가 높았다는 보고(8)와 상반되는 결과 보고 로 미루어 보아 절임 방법보다는 배추 자체의 품질 특성의 영향이 더 큰 것으로 여겨진다. 저장 기간 중의 조직감 변화 의 경우 경도는 전반적으로 가을배추보다는 여름배추가 약간 높은 경도 패턴을 보였다. 절임배추의 색도의 경우 본문에 표로 나타내지는 않았으나, 밝기를 나타내는 L값의 경우 전반적으로 제조 직후 계절별로 42.17 49.68의 범위로 유의적인 차이를 보이지 않았다. 적색도를 나타내는 a값은 - 6.07 -7.30, 황색도를 나타내는 b값은 13.77 15.98로 계 절별 절임배추간 유의적인 차이를 보이지 않았다. 그러나 저장 기간에 따른 시료의 $\mathrm{L}, \mathrm{a}, \mathrm{b}$ 값에서 제조 직후의 $\mathrm{L}$, $\mathrm{a}, \mathrm{b}$ 의 차이 값으로 환산된 $\Delta \mathrm{E}$ 값의 경우 초기 절임배추 색과 가장 큰 차이가 있었던 절임배추는 월동배추로 저장기 간이 증가함에 따라 $\Delta \mathrm{E}$ 값이 계속 증가하여 저장 21 일에는 $12 \sim 14$ 로 여름 배추는 $\Delta \mathrm{E}$ 값이 가장 낮은 4 6 범위의 색도 변화가 있었다. 또 여름배추와 봄배추의 경우도 월동 배추 와 유사한 패턴으로 $\Delta \mathrm{E}$ 값이 증가하였다.

한편 Table 1 은 저장 중 계절별 절임배추의 관능적 묘사 특성을 조사한 결과이다. 절임배추의 노란색의 경우 저장 기간이 증가함에 따라 전반적으로 계절별 절임배추에 상관 없이 감소하였다. 계절별 절임배추에 따른 평가 점수는 차 이가 있었는데, 봄배추의 경우 저장 14일까지는 9.4 11.4의 점수로 평가하다가 저장 21 일 이후에는 4.5 이하의 점수로 평가하였다. 여름배추는 저장 초기 8.8 7.3에서 저장 14 일 이후에는 4.1 이하의 점수로 평가하였고, 가을배추와 월동 배추는 저장 14 일까지 각각 8.8 10.9, 8.7 11.4에서 저장 21 일에는 각각 $4.2,3.0$ 이하의 점수로 평가하였다. 갈색도는 저장 기간이 증가함에 따라 월동배추는 증가하는 경향이었 으나, 다른 계절의 시료는 뚜렷한 증가 경향을 보이지 않았 는데, 이는 절임배추의 시료 부위의 차이로 관능검사시 평 가하기가 어려웠던 것으로 판단된다. 절임배추의 초록색 정도는 저장기간이 증가함에 따라 저장 전반에 걸쳐 감소하 는 경향을 보였고, 여름배추의 초록색 감소가 다른 계절의

Fig. 3. Changes in the textural properties and $\Delta \mathrm{E}$ value of seasonal salted-Kimchi cabbages in different storage periods.

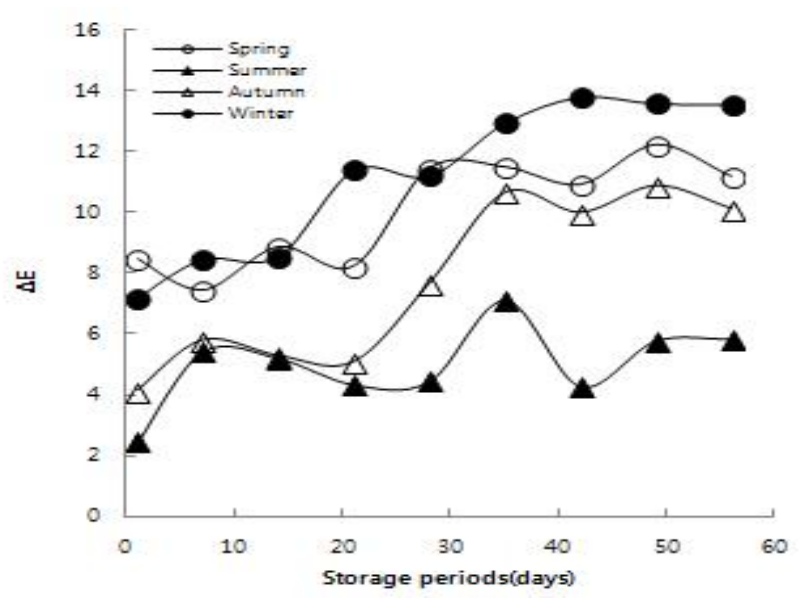


Table 1. Sensory evaluation of seasonal salted-Kimchi cabbages in different storage periods

\begin{tabular}{|c|c|c|c|c|c|c|c|c|c|c|c|c|c|c|c|c|c|}
\hline \multirow[b]{2}{*}{ Season } & \multirow[b]{2}{*}{ Day } & \multicolumn{4}{|c|}{ Appearance } & \multicolumn{4}{|c|}{ Aroma } & \multicolumn{6}{|c|}{ Taste } & \multicolumn{2}{|c|}{ Texture } \\
\hline & & Yellowness & Browness & Greeness & Glossiness & $\begin{array}{l}\text { Kimchi } \\
\text { cabbage }\end{array}$ & Saltiness & Sweetness & Sourness & $\begin{array}{l}\text { Kimchi } \\
\text { cabbage }\end{array}$ & Saltiness & Sweetness & Acridness & Bitterness & Sourness & Crispiness & Toughness \\
\hline \multirow{10}{*}{ Spring } & 0 & $9.4^{\text {al) }}$ & $2.7^{b c}$ & $12.0^{\mathrm{a}}$ & $9.7^{\mathrm{a}}$ & $7.7^{\mathrm{bc}}$ & $3.6^{b}$ & 5.7 & $1.3^{\mathrm{d}}$ & $7.8^{\mathrm{abc}}$ & $9.6^{\mathrm{a}}$ & $3.7^{\mathrm{a}}$ & 7.1 & 3.8 & $1.9^{d}$ & $11.8^{\mathrm{a}}$ & $3.8^{\mathrm{c}}$ \\
\hline & 1 & $11.3^{\mathrm{a}}$ & $1.4^{\mathrm{c}}$ & $8.5^{b c}$ & $8.6^{\mathrm{ab}}$ & $9.3^{\text {ab }}$ & $4.5^{\mathrm{ab}}$ & 7.4 & $2.0^{\mathrm{d}}$ & $10.2^{\mathrm{a}}$ & $7.8^{\mathrm{abc}}$ & $5.0^{\mathrm{a}}$ & 7.5 & 3.4 & $1.6^{d}$ & $10.2^{\mathrm{a}}$ & $4.5^{\mathrm{bc}}$ \\
\hline & 7 & $11.4^{\mathrm{a}}$ & $1.8^{c}$ & $10.7^{\mathrm{ab}}$ & $9.8^{\mathrm{a}}$ & $11.4^{\mathrm{a}}$ & $7.3^{\mathrm{ab}}$ & 6.3 & $1.8^{d}$ & $10.8^{\mathrm{a}}$ & $8.8^{\mathrm{ab}}$ & $5.8^{\mathrm{a}}$ & 7.2 & 4.0 & $2.8^{c}$ & $10.7^{\mathrm{a}}$ & $4.5^{\mathrm{bc}}$ \\
\hline & 14 & $10.6^{\mathrm{a}}$ & $2.2^{b c}$ & $9.9^{\mathrm{ab}}$ & $8.7^{\mathrm{ab}}$ & $10.9^{\mathrm{a}}$ & $6.0^{\mathrm{ab}}$ & 7.3 & $2.8^{\mathrm{cd}}$ & $10.3^{\mathrm{a}}$ & $5.8^{\mathrm{bc}}$ & $4.4^{\mathrm{a}}$ & 4.9 & 2.7 & $2.3^{\mathrm{c}}$ & $10.3^{\mathrm{a}}$ & $4.6^{\mathrm{bc}}$ \\
\hline & 21 & $4.5^{\mathrm{b}}$ & $5.0^{\mathrm{a}}$ & $9.7^{\mathrm{ab}}$ & $7.5^{\mathrm{abc}}$ & $8.6^{\mathrm{ab}}$ & $7.3^{\mathrm{ab}}$ & 4.7 & $4.8^{\mathrm{bc}}$ & $9.1^{\mathrm{ab}}$ & $4.8^{c}$ & $5.8^{\mathrm{a}}$ & 5.4 & 3.9 & $2.9^{\mathrm{c}}$ & $9.2^{\mathrm{bc}}$ & $4.6^{\mathrm{bc}}$ \\
\hline & 28 & $2.6^{b c}$ & $3.7^{\mathrm{bc}}$ & $7.0^{\mathrm{cd}}$ & $6.4^{b c}$ & $7.7^{\mathrm{bc}}$ & $7.3^{\mathrm{ab}}$ & 5.6 & $5.8^{\mathrm{ab}}$ & $6.1^{\text {bed }}$ & $7.0^{\mathrm{abc}}$ & $4.8^{\mathrm{a}}$ & 4.4 & 4.5 & $5.8^{\mathrm{ab}}$ & $8.4^{b c x}$ & $7.1^{\mathrm{ab}}$ \\
\hline & 35 & $3.2^{b c}$ & $4.0^{b c}$ & $6.0^{\mathrm{od}}$ & $6.2^{b c}$ & $5.4^{\mathrm{dd}}$ & $7.0^{\mathrm{ab}}$ & 6.3 & $7.9^{\mathrm{a}}$ & $7.1^{\text {bcd }}$ & $8.0^{\mathrm{abc}}$ & $4.7^{\mathrm{a}}$ & 5.3 & 4.9 & $5.1^{\mathrm{ab}}$ & $7.8^{\mathrm{cd}}$ & $7.0^{\mathrm{ab}}$ \\
\hline & 42 & $2.8^{\mathrm{bc}}$ & $3.8^{\mathrm{bc}}$ & $6.2^{\mathrm{cd}}$ & $6.0^{b c}$ & $5.4^{\mathrm{dd}^{2}}$ & $7.3^{\mathrm{ab}}$ & 5.0 & $7.9^{\mathrm{a}}$ & $4.6^{\mathrm{de}}$ & $5.8^{\mathrm{bc}}$ & $3.7^{\mathrm{a}}$ & 4.4 & 4.0 & $8.1^{\mathrm{a}}$ & $7.3^{\mathrm{d}}$ & $7.7^{\mathrm{a}}$ \\
\hline & 49 & $2.5^{b c}$ & $4.6^{b}$ & $4.9^{d}$ & $5.9^{b c}$ & $4.6^{d}$ & $8.3^{\mathrm{ab}}$ & 4.5 & $7.8^{\mathrm{a}}$ & $5.2^{\text {de }}$ & $7.3^{\text {abc }}$ & $4.3^{\mathrm{a}}$ & 5.2 & 5.5 & $7.4^{\mathrm{a}}$ & $7.3^{d}$ & $7.2^{\mathrm{ab}}$ \\
\hline & 56 & $1.6^{\circ}$ & $4.4^{b}$ & $4.8^{d}$ & $4.8^{c}$ & $4.5^{\mathrm{d}}$ & $5.2^{\mathrm{ab}}$ & 4.9 & $6.9^{\mathrm{ab}}$ & $4.2^{\mathrm{de}}$ & $7.0^{\mathrm{abc}}$ & $4.5^{\mathrm{a}}$ & 4.6 & 5.0 & $7.5^{\mathrm{a}}$ & $8.6^{\text {bod }}$ & $6.0^{\mathrm{abc}}$ \\
\hline \multirow{10}{*}{ Summer } & 0 & $8.8^{\mathrm{a}}$ & $2.0^{b c}$ & $11.6^{\mathrm{ab}}$ & $9.7^{\mathrm{a}}$ & $8.6^{\mathrm{ab}}$ & $4.2^{\mathrm{de}}$ & 5.5 & $1.2^{\mathrm{e}}$ & $10.3^{\mathrm{a}}$ & $5.5^{\mathrm{ab}}$ & $5.7^{\mathrm{abc}}$ & 4.1 & 3.0 & $1.4^{\mathrm{d}}$ & $10.9^{\mathrm{a}}$ & $4.9^{\mathrm{cd}}$ \\
\hline & 1 & $7.3^{\mathrm{a}}$ & $2.1^{b c}$ & $11.1^{\mathrm{ab}}$ & $8.6^{\mathrm{ab}}$ & $9.0^{\mathrm{a}}$ & $3.5^{\mathrm{e}}$ & 5.2 & $1.7^{e}$ & $9.6^{\mathrm{a}}$ & $4.5^{\mathrm{b}}$ & $5.3^{\mathrm{abc}}$ & 5.2 & 3.2 & $1.2^{\mathrm{d}}$ & $10.8^{\mathrm{a}}$ & $4.4^{\mathrm{d}}$ \\
\hline & 7 & $7.3^{\mathrm{a}}$ & $2.3^{b c}$ & $12.0^{\mathrm{a}}$ & $8.0^{\mathrm{ab}}$ & $8.6^{\mathrm{ab}}$ & $5.0^{\text {cde }}$ & 6.3 & $3.7^{\text {de }}$ & $9.8^{\mathrm{a}}$ & $4.8^{\mathrm{ab}}$ & $6.5^{\mathrm{ab}}$ & 5.0 & 2.1 & $2.7^{\mathrm{d}}$ & $10.7^{\mathrm{a}}$ & $4.5^{\mathrm{d}}$ \\
\hline & 14 & $4.1^{\mathrm{bc}}$ & $2.0^{b c}$ & $9.6^{\mathrm{bc}}$ & $7.3^{\mathrm{abc}}$ & $8.8^{\mathrm{ab}}$ & $4.9^{\mathrm{cde}}$ & 6.8 & $3.8^{\mathrm{de}}$ & $9.2^{\mathrm{ab}}$ & $4.4^{b}$ & $7.1^{\mathrm{a}}$ & 4.2 & 3.4 & $1.8^{d}$ & $10.0^{a}$ & $5.8^{\text {bad }}$ \\
\hline & 21 & $4.6^{b}$ & $2.6^{b c}$ & $8.2^{\mathrm{d}}$ & $7.1^{\mathrm{abc}}$ & $8.8^{\mathrm{ab}}$ & $5.7^{\text {bod }}$ & 7.5 & $5.1^{\mathrm{cd}}$ & $8.1^{\mathrm{abc}}$ & $5.2^{\mathrm{ab}}$ & $6.8^{\mathrm{ab}}$ & 5.7 & 3.9 & $3.6^{\mathrm{dd}}$ & $10.7^{\mathrm{a}}$ & $6.1^{\mathrm{abc}}$ \\
\hline & 28 & $1.2^{\mathrm{d}}$ & $2.0^{b c}$ & $9.9^{b c}$ & $4.5^{\mathrm{d}}$ & $7.9^{\mathrm{abc}}$ & $6.6^{\text {abcd }}$ & 6.5 & $6.6^{b c}$ & $8.5^{\mathrm{abc}}$ & $6.0^{\mathrm{ab}}$ & $5.9^{\mathrm{abc}}$ & 4.8 & 3.8 & $4.2^{\mathrm{bc}}$ & $10.1^{\mathrm{a}}$ & $7.2^{\mathrm{abc}}$ \\
\hline & 35 & $3.1^{\text {bed }}$ & $1.8^{\mathrm{c}}$ & $8.9^{\mathrm{d}}$ & $7.6^{\mathrm{abc}}$ & $6.8^{\text {bod }}$ & $6.3^{\text {abcd }}$ & 5.8 & $6.3^{\text {bcd }}$ & $8.0^{\text {abod }}$ & $4.3^{b}$ & $6.1^{\mathrm{abc}}$ & 4.4 & 3.3 & $3.9^{b c}$ & $9.9^{\mathrm{a}}$ & $6.3^{\mathrm{abc}}$ \\
\hline & 42 & $2.1^{d}$ & $2.8^{\mathrm{bc}}$ & $6.6^{f}$ & $6.9^{x}$ & $5.1^{d^{d}}$ & $7.5^{\mathrm{abc}}$ & 6.3 & $8.5^{\mathrm{ab}}$ & $5.6^{\mathrm{de}}$ & $5.8^{\mathrm{ab}}$ & $5.3^{\mathrm{abc}}$ & 4.3 & 5.1 & $5.0^{\mathrm{ab}}$ & $8.8^{\mathrm{ab}}$ & $7.0^{\mathrm{abc}}$ \\
\hline & 49 & $2.0^{\mathrm{d}}$ & $2.4^{b c}$ & $9.9^{b c}$ & $5.5^{\mathrm{cd}}$ & $5.8^{\mathrm{dd}}$ & $8.7^{\mathrm{ab}}$ & 6.1 & $8.0^{\mathrm{ab}}$ & $6.5^{\mathrm{bcd}}$ & $4.7^{\mathrm{b}}$ & $5.0^{\mathrm{abc}}$ & 5.1 & 4.1 & $4.9^{\mathrm{ab}}$ & $9.5^{\mathrm{ab}}$ & $7.7^{\mathrm{abc}}$ \\
\hline & 56 & $2.4^{\mathrm{dd}}$ & $3.4^{b c}$ & $9.2^{\mathrm{cd}}$ & $5.3^{\mathrm{cd}}$ & $4.0^{\mathrm{od}}$ & $9.1^{\mathrm{a}}$ & 5.6 & $9.8^{\mathrm{a}}$ & $5.3^{\mathrm{de}}$ & $5.2^{\mathrm{ab}}$ & $5.2^{\mathrm{abc}}$ & 3.5 & 3.8 & $5.0^{\mathrm{ab}}$ & $7.3^{\mathrm{bc}}$ & $7.2^{\mathrm{abc}}$ \\
\hline \multirow{10}{*}{ Autumn } & 0 & $10.8^{\mathrm{ab}}$ & $1.8^{\mathrm{bc}}$ & $12.5^{\mathrm{a}}$ & $8.2^{a b}$ & $7.5^{\text {abc }}$ & $1.8^{c}$ & 4.7 & $0.7^{e}$ & $10.2^{\mathrm{ab}}$ & $5.5^{\mathrm{ab}}$ & $6.5^{\text {abcd }}$ & 6.9 & 3.4 & $1.3^{d}$ & $12.6^{\mathrm{a}}$ & $3.1^{d}$ \\
\hline & 1 & $10.9^{\mathrm{a}}$ & $1.0^{c}$ & $9.8^{\mathrm{bc}}$ & $8.8^{\mathrm{a}}$ & $10.7^{\mathrm{a}}$ & $4.0^{\mathrm{bc}}$ & 7.0 & $1.6^{\mathrm{de}}$ & $11.4^{\mathrm{a}}$ & $3.8^{\mathrm{ab}}$ & $8.1^{\mathrm{ab}}$ & 7.5 & 2.5 & $0.8^{d}$ & $12.6^{\mathrm{a}}$ & $2.3^{\mathrm{d}}$ \\
\hline & 7 & $8.8^{b c}$ & $0.8^{c}$ & $10.8^{\mathrm{ab}}$ & $7.9^{\mathrm{ab}}$ & $10.9^{\mathrm{a}}$ & $4.1^{\mathrm{bc}}$ & 7.1 & $1.8^{\mathrm{de}}$ & $11.1^{\mathrm{a}}$ & $3.6^{b}$ & $8.7^{\mathrm{a}}$ & 5.6 & 2.5 & $0.6^{d}$ & $12.2^{\mathrm{ab}}$ & $3.3^{\mathrm{cd}}$ \\
\hline & 14 & $8.8^{\mathrm{bc}}$ & $1.6^{\mathrm{c}}$ & $11.3^{\mathrm{ab}}$ & $7.8^{\mathrm{ab}}$ & $9.8^{\mathrm{ab}}$ & $4.8^{\mathrm{bc}}$ & 6.3 & $2.5^{\mathrm{de}}$ & $10.2^{\mathrm{ab}}$ & $3.6^{b}$ & $6.8^{\mathrm{abcd}}$ & 7.2 & 3.0 & $1.9^{\mathrm{c}}$ & $11.3^{\mathrm{abc}}$ & $4.4^{\text {bod }}$ \\
\hline & 21 & $4.2^{d}$ & $4.2^{\mathrm{a}}$ & $8.9^{b c}$ & $6.3^{\mathrm{abc}}$ & $8.5^{\text {abc }}$ & $4.1^{b x}$ & 5.3 & $3.3^{\mathrm{cd}}$ & $8.9^{\mathrm{abc}}$ & $3.8^{\mathrm{ab}}$ & $7.3^{\mathrm{abc}}$ & 5.5 & 2.2 & $2.0^{\circ}$ & $10.2^{\text {bed }}$ & $5.7^{\text {abc }}$ \\
\hline & 28 & $3.7^{\text {de }}$ & $2.0^{b c}$ & $8.8^{c}$ & $7.0^{\mathrm{abc}}$ & $6.4^{\text {bcd }}$ & $4.9^{\mathrm{bc}}$ & 4.8 & $5.0^{b c}$ & $7.6^{\text {bod }}$ & $3.4^{b}$ & $5.7^{\mathrm{bcd}}$ & 5.5 & 4.2 & $3.0^{\mathrm{c}}$ & $9.3^{\text {cde }}$ & $6.2^{\mathrm{ab}}$ \\
\hline & 35 & $3.1^{\text {bdd }}$ & $2.0^{b c c}$ & $8.9^{b c}$ & $7.6^{\mathrm{abc}}$ & $6.8^{\text {bod }}$ & $6.3^{\text {abcd }}$ & 5.8 & $6.3^{\text {bd }}$ & $7.5^{\mathrm{bcd}}$ & $3.3^{b}$ & $5.5^{\mathrm{cbcf}}$ & 5.4 & 4.3 & $3.9 b^{c}$ & $9.9^{\text {acde }}$ & $6.3^{\text {abc }}$ \\
\hline & 42 & $2.7^{\mathrm{de}}$ & $2.6^{\mathrm{abc}}$ & $4.8^{\mathrm{de}}$ & $5.2^{b c}$ & $6.1^{\mathrm{dd}}$ & $6.0^{\mathrm{ab}}$ & 5.8 & $7.0^{\mathrm{ab}}$ & $7.7^{\text {bcd }}$ & $3.9^{\mathrm{ab}}$ & $5.5^{\mathrm{bcd}}$ & 5.7 & 4.5 & $3.8^{\mathrm{c}}$ & $9.0^{\mathrm{de}}$ & $6.1^{\mathrm{ab}}$ \\
\hline & 49 & $1.6^{\mathrm{e}}$ & $2.4^{\mathrm{abc}}$ & $9.8^{b c}$ & $5.2^{b c}$ & $4.8^{d}$ & $7.3^{\mathrm{a}}$ & 6.2 & $8.7^{\mathrm{a}}$ & $5.9^{\text {dde }}$ & $5.7^{\mathrm{ab}}$ & $4.3^{\mathrm{d}}$ & 5.0 & 4.8 & $5.0^{\mathrm{a}}$ & $8.4^{\mathrm{de}}$ & $7.4^{\mathrm{a}}$ \\
\hline & 56 & $2.2^{\text {de }}$ & $2.4^{\mathrm{abc}}$ & $6.3^{d}$ & $4.5^{\mathrm{c}}$ & $5.3^{\mathrm{dd}}$ & $6.9^{\mathrm{ab}}$ & 6.1 & $7.5^{\mathrm{ab}}$ & $5.3^{\mathrm{de}}$ & $5.1^{\mathrm{ab}}$ & $4.9^{\mathrm{cd}}$ & 3.6 & 3.2 & $4.4^{\mathrm{ab}}$ & $8.4^{d e}$ & $6.3^{\mathrm{ab}}$ \\
\hline \multirow{10}{*}{ Winter } & 0 & $11.3^{\mathrm{a}}$ & $0.9^{d}$ & $10.8^{\mathrm{a}}$ & $9.8^{\mathrm{a}}$ & $8.5^{\text {abod }}$ & $5.5^{\mathrm{d}}$ & 7.4 & $2.6^{e}$ & $10.8^{\mathrm{a}}$ & $4.8^{e}$ & $9.8^{\mathrm{a}}$ & 6.0 & $2.5 b$ & $1.2^{\mathrm{e}}$ & $12.2^{\mathrm{a}}$ & $3.8^{\mathrm{cd}}$ \\
\hline & 1 & $11.4^{\mathrm{a}}$ & $1.5^{\mathrm{c}}$ & $10.8^{\mathrm{a}}$ & $9.9^{\mathrm{a}}$ & $11.3^{\mathrm{a}}$ & $5.5^{\mathrm{d}}$ & 8.4 & $3.3^{\mathrm{e}}$ & $11.4^{\mathrm{a}}$ & $5.8^{\text {cde }}$ & $9.4^{\mathrm{a}}$ & 8.3 & $3.8 \mathrm{ab}$ & $2.0^{\mathrm{e}}$ & $12.4^{a}$ & $2.6^{d}$ \\
\hline & 7 & $9.9^{\mathrm{ab}}$ & $2.0^{c}$ & $9.4^{\mathrm{ab}}$ & $9.4^{\mathrm{a}}$ & $10.9^{\mathrm{a}}$ & $5.5^{\mathrm{d}}$ & 8.4 & $2.4^{\mathrm{e}}$ & $9.7^{\mathrm{ab}}$ & $5.3^{\mathrm{de}}$ & $9.4^{\mathrm{a}}$ & 5.6 & $2.8 \mathrm{~b}$ & $1.2^{\mathrm{e}}$ & $11.8^{\mathrm{ab}}$ & $3.8^{\mathrm{cd}}$ \\
\hline & 14 & $8.7^{b}$ & $3.9^{b c}$ & $8.3^{\mathrm{abc}}$ & $8.3^{\mathrm{ab}}$ & $10.2^{\mathrm{ab}}$ & $5.0^{d}$ & 8.2 & $4.5^{\mathrm{de}}$ & $10.0^{\mathrm{ab}}$ & $6.4^{\mathrm{bdd}}$ & $7.5^{\mathrm{ab}}$ & 6.5 & 5.1ab & $2.8^{\mathrm{de}}$ & $9.9^{\text {bed }}$ & $5.7^{b c}$ \\
\hline & 21 & $3.0^{\mathrm{de}}$ & $3.4^{b c}$ & $7.7^{\mathrm{bc}}$ & $5.6^{\text {bad }}$ & $6.8^{\mathrm{de}}$ & $6.6^{\mathrm{cd}}$ & 6.2 & $6.8^{\text {cd }}$ & $6.6^{\mathrm{dd}}$ & $5.1^{\mathrm{de}}$ & $7.0^{\mathrm{abc}}$ & 5.7 & $4.8 \mathrm{ab}$ & $4.7^{c}$ & $8.5^{\mathrm{cd}}$ & $5.3^{\text {bad }}$ \\
\hline & 28 & $3.4^{d}$ & $4.9^{\mathrm{ab}}$ & $7.9^{\mathrm{bc}}$ & $5.6^{\text {bod }}$ & $7.3^{\text {bcd }}$ & $7.4^{\text {bed }}$ & 5.8 & $6.7^{\text {bod }}$ & $7.8^{\mathrm{bcd}}$ & $5.4^{\mathrm{de}}$ & $6.8^{\mathrm{abc}}$ & 6.7 & $7.2 \mathrm{a}$ & $4.7^{\mathrm{c}}$ & $9.3^{\mathrm{cd}}$ & $7.2^{\mathrm{ab}}$ \\
\hline & 35 & $2.4^{\mathrm{de}}$ & $3.7^{b c}$ & $8.0^{b c}$ & $7.5^{\mathrm{abc}}$ & $7.0^{\text {od }}$ & $7.3^{\text {bdd }}$ & 6.5 & $6.1^{\mathrm{cd}}$ & $8.5^{\mathrm{abc}}$ & $7.3^{\text {abc }}$ & $6.3^{b c}$ & 5.5 & $4.7 \mathrm{ab}$ & $5.4^{b c}$ & $10.3^{\mathrm{abc}}$ & $5.6^{\mathrm{bc}}$ \\
\hline & 42 & $2.1^{\text {de }}$ & $5.8^{\mathrm{a}}$ & $2.8^{\mathrm{e}}$ & $5.1^{\mathrm{cd}}$ & $5.1^{e}$ & $7.3^{\text {bod }}$ & 7.3 & $8.0^{b c}$ & $6.7^{\mathrm{dd}}$ & $7.4^{\mathrm{abc}}$ & $4.3^{c}$ & 6.8 & $6.3 \mathrm{ab}$ & $5.9^{b}$ & $8.6^{\mathrm{cd}}$ & $5.8^{\mathrm{bc}}$ \\
\hline & 49 & $2.4^{\mathrm{de}}$ & $4.8^{\mathrm{ab}}$ & $4.3^{\mathrm{de}}$ & $4.3^{\mathrm{de}}$ & $6.0^{\mathrm{de}}$ & $7.6^{\text {bcd }}$ & 5.8 & $7.9^{b c}$ & $5.3^{\mathrm{de}}$ & $6.6^{\mathrm{bdd}}$ & $6.1^{\mathrm{bc}}$ & 6.0 & $6.0 \mathrm{ab}$ & $6.7^{b}$ & $7.8^{\text {cde }}$ & $7.8^{\mathrm{ab}}$ \\
\hline & 56 & $2.6^{\mathrm{de}}$ & $7.3^{\mathrm{a}}$ & $5.0^{\mathrm{de}}$ & $3.6^{\mathrm{de}}$ & $5.3^{\mathrm{e}}$ & $7.9^{\mathrm{abc}}$ & 6.8 & $9.1^{\mathrm{a}}$ & $5.1^{\mathrm{de}}$ & $8.2^{\mathrm{abc}}$ & $5.9^{b c}$ & 5.5 & $6.5 \mathrm{ab}$ & $7.2^{\mathrm{a}}$ & $8.5^{\mathrm{cd}}$ & $7.2^{\mathrm{ab}}$ \\
\hline
\end{tabular}


절임배추에 비해 평가 점수 폭이 낮았다. 이는 계절별 배추 특성에 따른 차이로 여겨진다. 또 절임배추의 표면 광택의 경우 계절별 절임배추와 상관없이 저장 기간이 증가함에 따라 초록색과 노란색 감소와 동일하게 점차 감소하는 패턴 을 보였다. 전반적으로 계절별 절임배추 고유의 노란색이 저장 14 일을 기준으로 다른 외관 품질 특성과 평가 점수가 감소 또는 증가속도가 완만한 것과 달리 뚜렷하게 감소된 낮은 점수로 평가하여 절임배추의 외관적 특성변화의 기준 이 되는 것으로 판단된다.

계절별 절임배추의 냄새특성 중 배추 냄새의 경우 저장 기간이 증가함에 따라 점차 감소하는 패턴을 보였는데 보통 의 점수인 7점을 기준으로 봄배추는 저장 35 일에 5.4 로 평 가하였고, 여름 배추는 저장 35 일에 6.8 , 가을배추는 저장 28 일에 6.4 , 월동배추는 저장 28 일에 6.8 로 평가하여 그 이상 저장한 경우에는 절임배추 고유 향이 없다고 평가하였 다. 짠 냄새의 경우는 절임배추 고유 냄새와 달리 저장 기간 이 증가함에 따라 점차 높은 점수로 평가하였는데, 7점을 기준으로 저장기간 내내 7점 내외의 점수보다 낮게 평가하 였다. 또 단냄새의 경우는 저장기간 내내 유의적인 평가 점수 차이를 보이진 않았다. 신냄새의 경우는 저장기간이 증가함에 따라 점차 증가하는 경향을 보였는데, 7점을 기준 으로 봄배추는 저장 35 일에 7.9 , 여름배추는 저장 42 일에 7.5 , 가을배추는 저장 49 일에 7.3 , 월동배추는 저장 49 일에 8.0 으로 평가하였다. 계절별 절임배추의 냄새 특성의 경우 저장 기간에 따라 절임배추의 냄새 변화가 계절별로 차이가 있는 것을 알 수 있었다. 한편 절임배추의 배추 맛은 저장이 진행됨에 따라 점차 감소하는 경향을 보였고, 짠맛은 저장 기간에 따라서는 뚜렷한 경향이 없이 봄배추는 5.8 9.6, 여름배추는 4.4 6.0, 가을배추는 3.3 5.7, 월 동배추는 5.1 8.2의 범위를 보였다. 단맛의 경우 저장기간 중 일정한 경향이 없었으나, 계절별로는 월동배추가 다른 계절의 절
임배추보다 전반적으로 높은 점수로 평가하였다. 절임배추 의 아린맛(매운맛)은 저장기간이나 계절별로 유의적인 점 수 차이가 없으면서 7점 이하의 점수로 평가하였다. 쓴맛의 경우는 월동배추를 제외하고는 저장기간이나 계절별로 크 게 차이가 없으면서 5점 이하의 점수로 평가한 반면 월동배 추는 저장기간이 증가함에 따라 약간 증가하는 경향을 보였 다. 신맛의 경우는 저장기간이 증가함에 따라 점차 높은 점수로 평가하는 경향이었고, 계절별로도 평가 점수에 차 이가 있었다. 이외에 절임배추 조직감의 경우 저장기간이 증가함에 따라 사각사각한 조직감은 감소하고 질긴 정도는 증가하는 경향을 보였다.

\section{품질특성간의 상관관계 및 통계분석}

저장 중 계절별 절임배추의 물리화학적 및 미생물 품질 특성의 상관관계를 측정하였다(Table 2). 계절별로 가용성 고형분 함량에 차이가 있었는데, 이는 $\mathrm{Ku}$ 등(24)과 Yoon 등(32)의 계절에 따른 배추의 절임 용수의 고형분 함량 변화 를 측정한 결과 월동 배추가 가장 많은 함량을 보였다는 결과와 Lee 등(17)의 가을배추의 가용성 고형분 함량이 봄 배추보다 많고 배추자체의 품종별보다 재배 계절에 따른 차이가 크다는 보고와 유사하게 계절별 배추에 따른 차이를 보였으며, 절임배추 저장 중에도 그 특성이 유지되었다. 절임배추 저장기간과 적정산도, $\Delta \mathrm{E}$ 값, 총균수, 젖산균수가 $1 \%$ 유의수준에서 양의 상관관계가 있는 반면, $\mathrm{pH}$ 와는 음의 상관관계를 보였다. 즉 절임배추 저장기간이 증가함에 따 라 적정산도, 미생물은 유의적으로 증가하고, $\mathrm{pH}$ 는 감소하 였다. 저장 중 절임배추의 $\mathrm{pH}$ 는 적정산도, $\Delta \mathrm{E}$ 값, 미생물 균수와 음의 상관관계를 보였다. 한편 Table 3 은 저장 중 계절별 절임배추 관능적 특성간의 상관관계를 분석한 결과 로 각 관능적 특성 항목간의 상관성이 있는 항목이 많았다. 계절별 절임배추와 단냄새, 단향과 $1 \%$ 유의수준에서 양의

Table 2. Correlation coefficients between the physicochemcial properties (Fig. 1 Fig. 3) in the seasonal salted-Kimchi cabbages

\begin{tabular}{|c|c|c|c|c|c|c|c|c|c|c|}
\hline Variables & Season & Day & $\mathrm{pH}$ & $\begin{array}{c}\text { Titratable } \\
\text { acidity }\end{array}$ & $\Delta \mathrm{E}$ value & Salt content & Soluble solid & $\begin{array}{c}\text { Total } \\
\text { microbes }\end{array}$ & $\begin{array}{c}\text { Lactic acid } \\
\text { bacteria }\end{array}$ & Hardness \\
\hline Season & 1 & -0.006 & 0.044 & -0.080 & 0.214 & -0.083 & 0.776 ** & -0.246 & -0.248 & -0.068 \\
\hline Day & & 1 & $-0.955^{\star \star}$ & $0.874^{* *}$ & $0.542^{\star *}$ & -0.043 & -0.271 & $0.593 * *$ & $0.604^{\star *}$ & 0.104 \\
\hline $\mathrm{pH}$ & & & 1 & $-0.930 * \star$ & $-0.491^{*}$ & 0.039 & 0.300 & $-0.555^{\text {** }}$ & $-0.562 * *$ & -0.168 \\
\hline Titratable acidity & & & & 1 & $0.361^{*}$ & 0.077 & -0.264 & $0.497^{*}$ & $0.504^{*}$ & $0.372 *$ \\
\hline$\Delta \mathrm{E}$ value & & & & & 1 & $0.415^{*}$ & 0.172 & -0.029 & 0.037 & -0.292 \\
\hline Salt content & & & & & & 1 & 0.181 & -0.317 & -0.188 & 0.022 \\
\hline Soluble solid & & & & & & & 1 & $-0.481^{*}$ & $-0.469^{*}$ & 0.112 \\
\hline Total microbes & & & & & & & & 1 & $0.959^{* \star}$ & 0.173 \\
\hline Lactic acid bacteria & & & & & & & & & 1 & 0.174 \\
\hline Hardness & & & & & & & & & & 1 \\
\hline
\end{tabular}

${ }^{*}$ significant at $\mathrm{p}<0.05,{ }^{*}$ significant at $\mathrm{p}<0.01$. 
Table 3. Correlation coefficients between sensory characteristics (Table 1) in seasonal salted-Kimchi cabbages

\begin{tabular}{|c|c|c|c|c|c|c|c|c|c|c|c|c|c|c|c|c|c|}
\hline & \multirow[b]{2}{*}{ Season } & \multicolumn{4}{|c|}{ Appearance } & \multicolumn{4}{|c|}{ Smell } & \multicolumn{6}{|c|}{ Flavor } & \multicolumn{2}{|c|}{ Texture } \\
\hline & & Yellowness & Browness & Greeness & Glossiness & $\begin{array}{l}\text { Kimchi } \\
\text { cabbage }\end{array}$ & Saltiness & Sweetness & Sourness & $\begin{array}{l}\text { Kimchi } \\
\text { cabbage }\end{array}$ & Saltiness & Sweetness & Acridness & Bitterness & Sourness & Ctispness & Toughness \\
\hline Season & 1.000 & 0.023 & 0.012 & -0.092 & -0.103 & 0.069 & -0.031 & $0.416^{\star}$ & 0.059 & 0.134 & -0.265 & $0.613^{\star \star}$ & 0.218 & 0.170 & -0.099 & 0.203 & -0.063 \\
\hline Yellowness & & 1.000 & $-0.542^{\star}$ & $0.654^{* *}$ & $0.882 * *$ & $0.817^{* *}$ & $-0.646^{* *}$ & $0.431^{*}$ & $-0.880 * *$ & $0.843^{* *}$ & 0.001 & $0.480^{*}$ & $0.596^{*}$ & $-0.590^{*}$ & $-0.791^{* *}$ & $0.808^{* *}$ & $-0.788^{* *}$ \\
\hline Browness & & & 1.000 & $-0.590^{*}$ & $-0.545^{\star}$ & $-0.450^{*}$ & $0.511^{*}$ & -0.290 & $0.533^{*}$ & $-0.530^{*}$ & 0.130 & $-0.324^{*}$ & -0.155 & $0.661^{1 *}$ & $0.605^{*}$ & $-0.610^{*}$ & $0.410^{*}$ \\
\hline Greeness & & & & 1.000 & $0.712^{\star \star \star}$ & $0.628^{* *}$ & $-0.561^{\star}$ & 0.094 & $-0.731^{\star \star}$ & $0.722^{* *}$ & -0.294 & $0.368^{*}$ & 0.197 & $-0.724^{* *}$ & $-0.784^{* *}$ & $0.751^{\star \star}$ & $-0.579^{\star}$ \\
\hline Glossiness & & & & & 1.000 & $0.774^{* *}$ & $-0.609^{*}$ & $0.329^{*}$ & $-0.856^{* \star}$ & $0.817^{* \star}$ & -0.035 & $0.428^{*}$ & $0.422^{*}$ & $-0.581^{*}$ & $-0.778^{* *}$ & $0.778^{\star *}$ & $-0.725^{\star *}$ \\
\hline Kimchi cabbage & & & & & & 1.000 & $-0.568^{\star}$ & $0.530^{*}$ & $-0.836^{* \star}$ & $0.903^{* *}$ & -0.186 & $0.616^{\star \star}$ & $0.501^{\star}$ & $-0.544^{*}$ & $-0.791^{\star *}$ & $0.787^{\star \star}$ & $-0.741^{\star *}$ \\
\hline Saltiness & & & & & & & 1.000 & -0.050 & $0.848^{* \pi}$ & $-0.653^{\star}$ & 0.304 & $-0.345^{\star}$ & $-0.352^{\star}$ & $0.672^{\star *}$ & $0.758^{\star \star}$ & -0.758 ** & $0.722^{* *}$ \\
\hline Sweetness & & & & & & & & 1.000 & -0.204 & $0.451^{\star}$ & 0.067 & $0.555^{*}$ & $0.375^{*}$ & -0.071 & $-0.342^{*}$ & $0.404 *$ & -0.289 \\
\hline Sourness & & & & & & & & & 1.000 & $-0.866^{* \star}$ & 0.151 & $-0.4377^{\star}$ & $-0.473^{*}$ & $0.704^{1 *}$ & $0.874^{* *}$ & $-0.874^{* *}$ & $0.823^{* *}$ \\
\hline Kimchi cabbage & & & & & & & & & & 1.000 & -0.272 & $0.628^{\star *}$ & $0.529^{*}$ & $-0.630^{*}$ & $-0.897 *$ & $0.868^{* \star}$ & $-0.768^{* \star}$ \\
\hline Satiness & & & & & & & & & & & 1.000 & $-0.446^{*}$ & 0.195 & $0.477^{*}$ & $0.402^{*}$ & -0.239 & 0.137 \\
\hline Sureetness & & & & & & & & & & & & 1.000 & $0.360^{*}$ & $-0.361^{*}$ & $-0.566^{*}$ & $0.633^{\text {* }}$ & $-0.429^{*}$ \\
\hline Acridness & & & & & & & & & & & & & 1.000 & 0.016 & $-0.372^{*}$ & $0.528^{\star}$ & $-0.559 *$ \\
\hline Bitterness & & & & & & & & & & & & & & 1.000 & $0.744^{* *}$ & $-0.674^{* \star}$ & $0.604^{*}$ \\
\hline Sourness & & & & & & & & & & & & & & & 1.000 & $-0.857^{\text {** }}$ & $0.75^{\star * *}$ \\
\hline Cispness & & & & & & & & & & & & & & & & 1.000 & $-0.794 * *$ \\
\hline Toughness & & & & & & & & & & & & & & & & & 1.000 \\
\hline
\end{tabular}

*significant at $\mathrm{p}<0.05,{ }^{*}$ significant at $\mathrm{p}<0.01$.

상관관계를 나타냈고, 외관의 노란색은 갈색, 짠냄새, 신냄 새, 쓴맛, 신맛, 씹힘성과 음의 상관관계가 있는 반면, 초록 색, 광택, 배추 냄새, 단냄새, 단맛, 아린맛, 아삭한 특성과는 양의 상관관계를 보였다. 전반적으로 저장 중 절임배추의 짠맛을 제외하고 관능적 품질 특성간의 유의적인 양 또는 음의 상관관계를 보여 절임배추 저장 중에 절임배추의 관능 적 품질 중 한가지 특성만 변화하는 것이 아니라 저장 기간 이 증가함에 따라 같이 변화한다는 것을 확인할 수 있었다.

저장 중 계절별 절임배추 품질 특성의 주성분 분석 (principal component analysis) 결과는 Fig. 4와 같다. 첫 번째 주성분(F1)과 두 번째 주성분(F2)는 전체 데이터의 $51.98 \%$ 와 $14.23 \%$ 의 설명력을 보여 주었고, 총설명력은 $66.21 \%$ 였 다. 주성분 $\mathrm{F} 1$ 은 저장기간, $\mathrm{pH}$, 적정산도, $\Delta \mathrm{E}$ 값, 미생물균수 와 관능적 품질 특성으로 외관 특성, 배추냄새, 짠내, 신내, 생배추맛, 아삭함과 질긴 정도였고, 주성분 $\mathrm{F} 2$ 는 가용성 고형분 함량, 경도였다. 각 품질 특성의 분포를 보면 $\mathrm{F} 1$ 의 오른쪽 위쪽 좌표에 소금함량, $\Delta \mathrm{E}$ 값, 짠맛, 쓴맛, 갈색도, 신맛과 냄새 요인이 위치하였고, 오른쪽 아래 좌표에는 적 정산도, 저장기간, 질김성, 미생물 균수 요인이 위치하였다. 반면에 F2 상으로 Y축 양의 방향으로 계절별, 가용성 고형 분 함량, 단맛과 냄새, 아린맛, 노란색, 배추 냄새가 위치하 였고, 왼쪽 아래쪽 좌표에는 생배추 맛, 아삭거림, $\mathrm{pH}$, 광택, 초록색정도, 경도가 위치하였다. 절임배추의 전반적인 특
성이 F1과 F2 그래프 상에 전체적으로 분포되어 있었는데, 계절과 가장 관련이 있는 요인은 가용성 고형분 함량, 단냄 새와 맛 및 아린맛이었다. 또 배추의 고유 맛과 냄새가 아삭 거리는 조직감, 광택, $\mathrm{pH}$ 가 가까운 위치에 있어 서로 상관성 이 높음을 알 수 있었고, 반면에 저장기간과 적정산도, 신맛, 질긴 정도가 가까운 위치에 있어 서로 상관성이 높았다. 한편 저장중 계절별 시료의 경우 월동배추는 $\mathrm{F} 1$ 상의 위쪽 에 분포하였고, 봄배추는 중반에 나머지 계절별 절임배추 는 F2상의 아래쪽에 분포하였다. 또 저장기간에 따라서는 $\mathrm{F} 1$ 상의 왼쪽에 저장 일수가 적은 절임배추 시료가 오른쪽 에는 저장 일수가 많은 시료가 위치하였다. 이는 계절별 절임배추의 물리화학적, 미생물학적 및 관능적 특성이 차 이가 제조 초기부터 전체적으로 품질에 차이가 있고, 저장 기간이 증가하여도 계절별로 품질의 차이가 있는 것을 알 수 있었다.

이상의 결과에서 절임배추로서의 상품성 유지 기간을 Lee 등(17)과 Park 등(30)의 상품으로 판매되고 있는 절임배 추의 $\mathrm{pH}$ 기준 5.94 6.11로 할 경우 월동배추와 여름 배추는 약 7일, 여름배추와 봄배추는 14 일까지로 볼 수 있다. 또 총산도 0.3 이하를 기준으로 보면 가을배추는 약 30 일, 봄배 추는 21 일, 여름배추와 월동배추는 약 14 일까지 상품성 유 지 기간으로 볼 수 있었다. 미생물균 수의 경우 계절별 절임 배추에 따라 다르게 나타나 여름배추는 약 7일 이후 균수가 




Fig. 4. Principal component analysis of the physicochemical properties and sensory characteristics of seasonal slated-Kimchi cabbage. SP, spring salted-Kimchi cabbages; SU, summer salted-Kimchi cabbages; AU, autumn salted-Kimchi cabbages; WI, winter salted-Kimchi cabbages.

급속하게 증가하여 저장 기간 내내 그 수를 유지한 반면 나머지 계절 배추는 서서히 증가하여 약 30 일 이후에는 그 수를 유지하였다. 또 관능검사의 경우도 절임배추의 노 란색을 기준으로 보면 약 14 일을 기준으로 낮은 점수로 평가하였으나, 냄새와 맛의 경우는 저장 기간이 증가함에 따라 서서히 낮은 점수 또는 높은 점수로 평가하여 상품성 유지기간을 정확하게 제시할 수 없었다. 그러나 본 연구결 과 계절에 상관없이 절임배추를 $0^{\circ} \mathrm{C}$ 에서 저장할 경우 약 14 일은 절임배추로의 상품성이 있는 것으로 판단되었다. 또 절임배추로의 상품성은 떨어지나 본 연구 목적의 하나인 김치제조 공장에서 저장된 절임배추로 김치를 제조할 경우

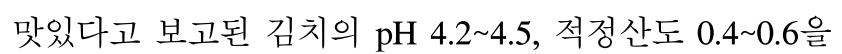
기준으로 약 50 일 정도 경과된 절임배추를 이용하여 김치 를 제조할 경우 익은 김치로의 상품성을 유지될 수 있다는 것이 예측되었다. 현재 저장 절임배추를 이용하여 김치제 조를 하여 물리화학 품질, 미생물 균수 및 관능검사를 진행 하고 있어 절임배추의 상품 유지기간과 김치 원료의 상품 유지기간을 설정할 수 있을 것으로 사료된다.

\section{요 약}

본 연구는 계절별 절임배추의 품질 균일화를 위한 기초 자료를 제공할 목적으로 저온 저장 중 물리화학적, 미생물 학적 및 관능적 품질 특성 조사하였다. 전반적으로 계절별 (봄배추, 여름배추, 가을배추 및 월동배추) 절임배추의 제조 직후 $\mathrm{pH}$ 는 저장 초기 계절별 시료 간 차이를 보이다가 저장 후반에는 시료 간 차이가 없었다. 적정산도는 가을 절임 배추가 비교적 낮은 산도를 보였고, 가용성 고형분 함량은 월동배추가 비교적 높은 함량을 보였으며, 미생물 균수는 여름배추가 가장 높은 균수를 보였다. 관능검사의 경우 계 절별 절임배추의 외관의 변화 냄새와 맛 특성 변화도 계절 별 시료에 따라 차이가 있었고, 관능적 품질 특성 항목간의 상관관계 분석결과 유의적으로 양 또는 음의 상관성을 보이 는 품질 특성이 많아서 절임배추 저장 중에 한 개의 품질 특성만 변화하는 것이 아니라 여러 가지 특성이 함께 변화 한다는 것을 확인할 수 있었다. 한편 계절별 절임배추 전반 적인 품질 특성의 주성분 분석 결과 첫 번째 주성분 $(\mathrm{F} 1)$ 과 
두 번째 주성분(F2)는 전체 데이터의 $51.98 \%$ 와 $14.23 \%$ 의 설명력을 보여 주었고, 총설명력은 $66.21 \%$ 였다. 계절별로 월 동배추는 F1상의 위쪽, 봄배추는 중간, 나머지 시료는 F2상의 아래쪽에 분포하였고, 저장기간에 따라서는 F1상 의 왼쪽에 저장 일수가 적은 절임배추 시료가 오른쪽에는 저장 일수가 많은 시료가 위치하였다. 본 연구 결과 계절별 절임배추의 품질 특성이 제조 직후부터 저장 중에도 계속 시료 간 품질 차이가 뚜렷하게 있음을 확인하였다. 그러므 로 품질이 균일화된 절임배추를 연중 소비자에게 제공하기 위해서 계절별 절임배추의 품질 특성과 저장 중의 차이를 고려하여 고품질의 절임배추 제조와 품질을 유지할 수 있는 연구 및 계절별 저장 절임배추를 이용한 김치 제조 연구가 지속되어야 한다고 판단된다.

\section{감사의 글}

본 연구는 농림축산식품부 - 농림수산식품기술기획평 가원 첨단생산기술개발사업의 연구비 지원으로 수행되었 으며, 이에 감사드립니다.

\section{References}

1. Ministry of agriculture food and rural affairs $(2010,2011)$ Korea agro-fisheries \& food trade corp Raw material consumption survey according to food industry, Korea

2. Agricultural outlook (2014) New challenges and the future of rural E04-2014. 17th Agricultural outlook, Korea Rural Economic Institute, Korea, p 364-424

3. Lee JY (2004) A simplified method to evaluate major quality factors and its application to determine inheritability of tissue firmness and total soluble solids in Chinese cabbage. MS Thesis, Chung-Ang University, Korea

4. Ku KH, Jeong MC, Chung SK (2013) Industrialization of salted Chinese cabbages and fresh-cut Chinese cabbage. Food Sci Indus, 46, 2-11

5. Ministry of Agriculture and Forestry (MAF) (2012) Statistics of vegetables production amount. MAF (http://www.mifaff.go.kr)

6. Han GJ, Choi HS, Lee SM, Lee EJ, Park SE, Park KY (2011) Addition of starters I pasteurized brined baechu cabbage increased Kimchi quality and health functionality. J Korean Soc Food Sci Nutr, 40, 110-115

7. Lee KH (2008) Effect of ozone treatment for sanitation of Chinese cabbage and salted Chinese cabbage. J Korean
Soc Food Sci Nutr, 37, 90-96

8. Lee SW, Cho SR, Han SH, Rhee C (2009) Effects of the low temperature and low salt solution on the quality characteristics of salted Chinese cabbage. J Korean Soc Food Sci Nutr, 22, 337-386

9. Park SS, Sung JM, Jeong JW, Park KJ, Lim JH (2013) Quality changes of salted Chinese cabbages with electrolyzed water washing and a low storage temperature. J Korean Soc Food Sci Nutr, 42, 615-620

10. Lee MK, Yang HJ, Woo HN, Rhee YK, Moon SW (2011) Changes in the texture and salt contents of Chinese cabbage using different salting methods. J Korean Soc Food Sci Nutr, 40, 1184-1188

11. Kim JH, Park KY, Choi HS, Yang JY (2010) Quality evaluation of conventional salted cabbages. J Korean Soc Food Sci Nutr, 23, 659-663

12. Kim HO, Suh SR, Choi YS, Yoo SN (2007) Optimal conditions for mechanized salting process of salt-inserting method for winter cabbage to produce Kimchi. Korean J Food Preserv, 14, 695-701

13. Lee MH, Lee GD, Son KJ, Yoon SR, Kim JS, Kwon JH (2002) Changes in organoleptic and rheological properties of Chinese cabbage with salting condition. J Korean Soc Food Sci Nutr, 3, 417-422

14. Hwang ES (2010) Changes in myrosinase activity and total glucosinolate levels in Korean Chinese cabbages by salting conditions. Korean J Food Cookery Sci, 26, 104-109

15. Kim YW, Jung JK, Cho YJ, Lee SJ, Kim SH, Park KY, Kang SA (2009) Quality changes in brined baechu cabbage using different types of polyethylene film and salt content during storage. Korean J Food Preserv, 16, 605-611

16. Kim MJ, Hong GH, chung DS, Kim YB (1998) Quality comparison of Kimchi made from different cultivars of Chinese cabbage. Korean J Food Sci Technol, 39, 528-532

17. Lee IS, Park WS, Koo YJ, Kang KH (1994) Changes in some characteristics of brined Chinese changes of fall cultivars during storage. Korean J Food Sci Technol, 26, 239-245

18. Han ES (1994) Quality changes of salted Chinese cabbage by packaging methods during storage. Korean J Food Sci Technol, 26, 283-287

19. Han KY, Noh BS (1996) Characterization of Chinese cabbage during soaking in sodium chloride solution. Korean J Food Sci Technol, 28, 707-713 
20. Han ES, Koo BY, Kim KH (2000) Cooling and packing characteristics of salted Baechu. Food Eng Prog, 4, 156-161

21. Han ES (1993) Salting storage method of highland Chinese cabbage for Kimchi. Korea J Food Sci Technol, $25,118-122$

22. Han ES, Seok MS, Park JH, Lee HJ (1996) Quality changes of salted cabbages with the package pressure and storage temperature. Korea J Food Sci Technol, 28, 650-656

23. Kim JH, Lee YK, Yang JY (2011) Change of harmful microorganisms in pickling process of salted cabbage according to salting and washing conditions. J Food Hyg Safety, 4, 417-423

24. $\mathrm{Ku} \mathrm{KH}$, Choi EJ, Jeong MC (2014) Comparison of quality characteristics between seasonal cultivar of salted-Kimchi cabbagess (Brassica rapa L. ssp. Pekinesis). Korean J Food Preserv, 21, 512-519

25. AOAC (1990) Official method of analysis. $15^{\text {th }}$ ed. Association of official analytical chemists, Washington DC, USA, p 607

26. AOAC (1990) Official method of analysis. $15^{\text {th }}$ ed. Association of official analytical chemists, Washington DC, USA, p 1006

27. Collins CH, Lyne PM (1985) Microbiological methods. $5^{\text {th }}$ ed. Butterworth \& Co. Ltd., Boston, p 73, 130-133

28. Hutchings JS (1994) Food colour and appearance.
Blackie Academic \& Professional, Colmworth, Bedford, U.K. p 217-223

29. Mailgarrd M, Civille G, Carr B (2007) Descriptive analysis techniques. CRC press, Boca Rato, FL, USA. p 173-186

30. Park WS, Lee IS, Han YS, Koo YJ (1994) Kimchi preparation with brined Chinese cabbage and seasoning mixture stored separtely. Korean J Food Sci Technol, 26, 231-238

31. Kim WJ, Ku KH, Cho HO (1988) Changes in some physical properties of Kimchi during salting and fermentation. Korean J Food Sci Technol, 20, 483-487

32. Yoon HH, Kim DM (2000) Changes of brine characteristics during the salting process of winter, spring and summer Chinese cabbage. J Korean Soc Food Sci Nutr, 29, 26-29

33. Lee KH, Kuack HS, Jung JW, Lee EJ, Jeong DM, Kang KY, Chae KI, Yun SH, Jang MR, Cho SD, Kim GH, Oh JY (2013) Comparison of the quality characteristics between spring cultivars of Kimchi cabbage (Brassica rapa L. ssp. pekinesis). Korean J Food Preserv, 20, 182-190

34. Lee JS, Choi JW, Chung DS, Lim CI, Park SH, Lee YS, Lim SC, Chun CH (2007) Cold storage, packing and salting treatments affecting the quality characteristics of winter Chinese cabbages. Korean J Food Preserv, 14, 24-29 